\title{
An Overview of the Sustainability of Solid Waste Management at Military Installations
}

\author{
Sharon Borglin ${ }^{1}$, Jennifer Shore, Heather Worden and Ravi Jain \\ ${ }^{1}$ Lawrence Berkeley National Laboratory, Berkeley, CA \\ Environmental Engineering Research Program, School of Engineering and Computer \\ Science, University of the Pacific, Stockton, California
}

\begin{abstract}
Sustainable municipal solid waste management at military solutions necessitates a combined approach that includes waste reduction, alternative disposal techniques, and increased recycling. Military installations are unique because they often represent large employers in the region in which they are located, thereby making any practices they employ impact overall waste management strategies of the region. Solutions for waste sustainability will be dependent on operational directives and base location, availability of resources such as water and energy, and size of population. Presented in this paper are descriptions of available waste strategies that can be used to support sustainable waste management. Results presented indicate source reduction and recycling to be the most sustainable solutions. However, new waste-to-energy plants and composting have potential to improve on these well proven techniques and allow military installations to achieve sustainable waste management.
\end{abstract}

\section{Introduction}

Sustainability of MSW management is important due to several factors. Reducing waste preserves natural resources, can minimize health and environmental impacts, and can support the economy. As world's resources are become more strained, sustainable solutions are becoming more necessary. However, in order to be successful, these solutions have to be socially acceptable, and be done while achieving a high standard of living and without compromising future generations.

Solid waste management at military institutions represents a significant portion of the operating costs for the Department of Defense. Overall costs are rising, regulations are becoming more stringent, and landfill space is limited and decreasing. The installations operated by the Department of Defense (DOD) are required to follow Federal and applicable state laws when handling MSW. These regulations include RCRA, Title 40 parts 240-272, Pollution Prevention Act of 1990. There are also regulations that apply directly to military installations including Federal Facilities Compliance Act, Federal Property and Administrative Services Act, US Code 2577 with the regards to thee disposal of recyclable materials, Military Construction Codification Act of 1982. DOD requires each installation to develop an integrated solid waste management plan (ISWMP). In addition, several Executive orders (EO) direct the policies at installations, 
including EO 13101, Greening the Government, EO 12856, which defines federal compliance with the pollution prevention act and EO 12780 which encourages federal agencies to reduce, reuse, and recycle. (Basham, Ferguson et al. 2004)

The scale and options for waste disposal for each military installation is regionally dependent because of variations in climate, and size of population, traffic, noise, and local regulations. Although military intuitions range widely in both size and activity they are similar to municipalities in many of their daily activities. But the installations are well-defined and more controlled, waste types more predictable, and DOD oversight can have more influence over the waste stream direction. The DOD is a proven early adapter of environmental polices (Hardcastle 2003; Bost 2004; Services 2005) and strive to have 'zero boot print'. Recent building guidelines require new construction to adhere to LEED silver construction certification(Haselbach 2008). This has led to adoption of alternative energy sources, such as solar power, and improvement in barrack design to optimize efficiency. In addition, technologies developed to increase efficiency of waste management military operations can be important in contingency operations to enhance military readiness when dependence of local resources for waste management is not feasible, thereby making waste management closely tied to military readiness and sustainability of military operations(Command 2005). The DOD has very high performance requirements, but they are making efforts to maintain necessary standards while reducing environmental impacts.

MSW handling activities include storage, collection, segregation, transportation, treatment, recycling, and disposal. Sustainable solutions can include source reduction, local composting, recycling, incineration or waste to energy plants, landfilling, or other more novel solutions. Solid wastes are typically handled and disposed of in one or more of several ways, including shredding, baling, source separation, recycling, composting, pyrolysis, incineration and heat recovery, and land disposal (e.g., sanitary landfill). The objectives of this study are to evaluate the current state of MSW management at military institutions, look at technology alternatives, and evaluate feasibility of management schemes or paradigm shifts. The types and quantities of solid wastes generated will vary geographically and seasonally. Military installations often have unique activities that generate wastes not found in ordinary municipal wastes. Furthermore, populations at military installations do not follow a normal growth pattern because the growth is controlled by mission requirements. Some challenges for sustainable waste management military are lack of agility for change. As with all communities they grapple with education and resistance to new procedures, as well as balancing convenience with environmental sustainability.

Each MSW processing solution will be described, and then evaluated using techniques similar to those described in Chifos and Jain (1997). The MSW technology will be assessed on feasibility, ease of use (social acceptance), education requirement, technology needs for further development, infrastructure needs, land use needs, greenhouse gas emissions, potential for pollution, and economics. Using this approach we will make general conclusions about the sustainability of each solution. 


\section{Nature and Extent of the Problem}

The disposal solutions at military installations vary widely from base to base. Very few of the installations currently operate on-site waste disposal, opting instead to rely on civilian contractors for MSW handling. Due to government imposed mandates (EO 13101, (Clinton 1998) all bases were required to have a solid waste diversion rate of $40 \%$ of the 1998 levels by 2005, prompting early adoption of waste minimization and recycling programs. The waste reduction goal was met in FY 2001 when the diversion rate reached 45\%. (Clinton 1998; Command 2005).

Some unique aspects of military installations are due the fact that they are federally owned and operated facilities. They contain a mixture of civilian employees and armed forces. Nationwide there are 5904 military bases with 1.7 million civilian and military personnel, with civilian personnel account for 25\% of total (ASTSWMO 2007; DOD 2007). Overall, the federal government employs $2 \%$ of United States residents making it the largest overall US employer. In addition, military installations are in diverse locations which necessitate a variety of customized solutions.

Military bases also have different demographics than the general population (USCensusBureau 2000; DOD 2007) (see Table 1). The overall age distribution is younger and has a proportionally higher male population than the US population at large. Many of the military personnel live in base housing and do not have direct responsibilities over grounds maintenance (as in a civilian residences) creating a more controlled waste stream for landscaping waste. Military cafeterias have the advantage of scale for control over source reduction, reuse, and recycling of waste (USArmy 1994). Education and training of the younger population on sustainable waste management will, hopefully, have an effect of practices for the rest of the lifetime of the soldier and soldier's family after leaving the military.

There are a few different categories of waste that are produced by the military. DOD facilities produce munitions which are considered MSW under some circumstances. Residential waste typically includes wastes from single and multi-family dwellings, bachelor officer's quarters, and troop housing and can consists typically of paper, glass, metal, plastics, food wastes, and other miscellaneous items. (Table 2) They also produce institutional waste from administration offices, commissaries, food service, medical facilities, warehouse, post exchanges, schools, and labs. From shops, motor pools, point shops, service stations the installations produce industrial waste. Construction and Demolition (C \& D) waste is also a major waste stream, a major source of waste for the military, will not be considered in this discussion. Due to the large land holdings and of DOD, green waste is also a major consideration. Other waste could include universal waste, batteries, computers, and hazardous waste.

The costs of MSW management are high and on the rise. Army MSW costs totaled $\$ 97.2$ million to dispose of 1.6 metric tons of MSW, not including construction and demolition debris. (DefenseEnvironmentalPrograms 2006). The Navy produces 600,000 tons of MSW annually, at a cost of 50 million (Navy February, 1999). Costs for MSW handling 
are due to multiple activities include storage, collection, segregation, transportation, treatment, recycling, and disposal. As fuel costs rise, regulations become more stringent, and landfills are located farther away from urban population centers, new solutions are necessary.

Recent findings by Congress states in regards to the current state of military installation solid waste management " significant savings could be realized by conserving materials in order to reduce the volume or quantity of material which ultimately becomes waste”(USArmy 2007). The document further state the economic and fuel value of MSW, since it contains combustible materials that can be use for energy generation and are a source metals which are becoming increasingly scarce and thereby more valuable, and that commercially viable technologies exist that should be supported by the Federal government including the DOD. (USArmy 2007)

\section{Source Reduction}

When looking at all options of MSW management the biggest gain, both economically and for the environment, is potentially in source reduction. A huge part of nonsustainability of current conditions is increase in waste. During the past 35 years, the amount of waste each person creates has almost doubled from 2.7 to 4.4 pounds per day (Cheremisinoff 2003; EPA 2008). One study of the waste stream from an Australian Army camp showed an increase of $15.8 \mathrm{lb} /$ day in 2003 to $18.2 \mathrm{lb} /$ day in 2006, a 15\% increase in 3 years (AustralianGovermentDOD 2004). Increase in consumerism and packaging were highlighted as main factors in the increase in overall waste (UNEP/GRID 2008). The United States is the largest producer of packaging waste in the world (see Figure1, (UNEP/GRID-Arendal 2006) In contrast, lower income countries have a high percentage (40-85\%) of food waste and little packaging or plastic waste (Tchobanoglous, Theisen et al. 1993)

Source reduction was first mandated for DOD facilities by the pollution prevention act of 1990 (United States code title 42, 'The public health and welfare code Title 42 chapter 133). Executive Order 13101 directed that all government agencies will develop a strategic plan to achieve waste reduction by examining procurement procedures, alternative packaging, and alternative work procedures (Clinton 1998). Integrated solid waste management plans (ISWMP) detail the procedures used to achieve waste diversion goals by engaging in source reduction. (Tchobanoglous, Theisen et al. 1993; AirForce 1994; USArmy 1994; USArmy 1994; USArmy 1994; Clinton 1998; Medicine 1999; Porter 2002). The main strategy in source reduction is considering the entire life-cycle of procured or produced materials and comprises altering the design, manufacturing, use of

products to reduce toxicity or volume of waste. Source reduction at a military installation is a multi-departmental cooperative effort and therefore collaboration between procurement, technical services, housing, food service, grounds maintenance, and personnel is necessary for success. Some typical source reduction strategies used are two sided copying of paper, using electronic rather than hard copy documentation, re-usuable utensils and plates for food service, transport package reduction, environmental preferable (green) purchasing. Green purchasing entails sourcing items with less 
packaging, purchasing repairable and reusable items, and recycling when an item reaches the end of life. Source reduction planning methods are outlined in several DOD publications (USArmy 1994; USArmy 1994; Medicine 1999).

Table 3 outlines an analysis as an example of source reduction planning. Options for bag type to be use for collection of compost are listed and costs, advantage, and disadvantages are considered. Some factors may include availability, function, cost, recycling and reuse potential, and ultimate disposal (Porter 2002).

One of the key aspects of source reduction is energy and resource savings from avoiding the production and processing of new materials. New materials take many times energy and resources than are utilized by re-use and recycling. Extraction of minerals due to mining accounts for 2.5 billion tons of waste a year, and does so with severe environmental impacts (Porter 2002). Agricultural production and animal waste results into severe water pollution problems, requires the use of harmful chemicals such as pesticides and antibiotics (Porter 2002). Packaging, while a large waste stream for the United States, can also be considered as waste reduction strategy because it preserves food and other items from spoilage during transport. Items that are canned, wrapped, or sealed in plastic, glass, and metal last longer on shelves. A recent trend in increased packaging of 'fresh' produce is aimed to increase shelf life. However, packaging is a large component of the waste stream (see Figure 1) and buying only the food and supplies that are needed will have a substantial impact on the amount entering landfills.

A large waste stream target for source reduction is landscaping or 'green waste'. Military installations often include large areas of landscaping. Landscaping waste requires collection, transport and disposal. Modification of landscape will reduce the amount of green waste created and this beneficial landscape design can provide pollution prevention (reduction of chemical use), waste reduction, and energy savings by the use of droughttolerant slow growth plantings appropriate for the region (USCoastGuard 1994). In addition, spacing of planting and conservative pruning will reduce waste. Shredded trimmings can be used as mulch. Replacement of grass lawns with slow-growth, drought-tolerant ground covers to reduce the need for mowing, reduce water consumption and reduce waste production. Depending on the primary use of the installation, new generation artificial turf can be installed instead of live grass. However, it should be noted, although the turf is made primarily from recycled materials and does not produce waste during use, the estimated lifetime for these surfaces is 15 years and no acceptable disposal methods have yet been developed.

\section{Recycling}

Recycling is a top choice among military institutions as a method of reducing municipal solid waste volumes. Recycling saves energy and natural resources by reusing items such as aluminum, steel, paper, and plastics. By recycling military institutions can reduce the amount of solid waste that must be landfilled thereby reducing disposal costs. The market for post-consumer recycled paper products is ever expanding, and many military installations find that there is a profit in recycling cardboard and other paper materials. In 
order for recycling to be successful, the economics of collection and sale of raw materials need to balance, there needs to be a market demand of source materials for reuse, basewide education or incentives may have to be utilized to increase involvement to encourage personnel to participate, and used of the recycling system has to be convenient and fit into work flow and living patterns. For recycling, as with many processes, there is a constant need of technical advances to make processing more efficient. One key aspect of efficiency is the minimization of transportation costs for collection and delivery.

Recycling has been a successful method used by the military to increase the amount of material diverted from the landfill as mandated by EO 13101 (Clinton 1998; Command 2005). This order required the development of recycling programs and purchasing of post consumer materials.

Most military institutions have four different steps that must be managed in the recycling process.

1. Collection of recyclables

2. Sorting/Storage

3. Sale/Marketing

Collection of recyclables varies based on the Qualified Recycling Program (QRP) management, size and residential composition of the base, and resources available (Army 2001). For example a military base with Military Family Housing (MFH), may offer collection on a weekly basis similar to that of solid waste collection, Typically a general separation of recyclables is required, and residents must separate mixed paper from plastic steel and aluminum as well as corrugated cardboard. Other military installations such as Newport Naval Station have specific recycling stations where employees, and residents can drop off presorted and cleaned (in the case of plastic and metal containers) recyclable material. The recyclables are then transferred to larger recycling centers by janitorial staff.

Sorting of recyclable goods begins in the collection phase. Military bases with QRP's need to employ base education efforts to make residents aware of what types of materials are recyclable, and how to prepare recyclable products for collection. Proper sorting by participants in the recycling program will ease sorting efforts required by the recycling center. For example, many bases will recycle number 1-Polythylene (PET) and number 2high density polyethylene (HDPE). Table 4 provides a list of recyclable goods typically collected at military installations and Table 5 lists some EPA-suggested recyclables (USArmy 1999; EPA 2008).

Sorting of recyclables can also be accomplished by mechanical equipment such as centrifuges, magnetism conveyors, and air classifiers. This equipment can be costly and will require an initial investment by the military installations. Hand sorting of recyclables is another option employed by military installations, however it requires costly manpower. After recyclables have been sorted they may be baled and stored or they may be directly transferred to a collector broker, or end user. By baling and storing the recycled good QRP managers can guarantee uniform quantities to buyers. Storage also 
provides a buffer in times of low market value of recycled goods. Storage and bailing does require additional space and investment of baling equipment, forklifts, dollies, or conveyors.

The marketing and sale of collected recyclable goods from military installations is a key component to a successful QRP. A successful QRP will generate revenue for the military installations even in times of low market value and low volumes of recyclable goods. The Army Corps of Engineers (USACE) in its technical bulletin "Direct Sale of Recyclables" outlines six general methods for marketing recyclable waste(Army 2001):

- Collectors- haulers who will remove recycled materials from the MI at a low price and sell them to a processor or broker.

- Processors- collect then process the recycled goods before selling to an end user or broker.

- Contract with Broker- brokers have contacts will a large number of end users in various markets. Brokers will purchase recycled goods from a military installations consolidate the goods from multiple sources and then sell larger volumes to the end user. A broker's service is best suited to small military installations in a remote location.

- Contract with End User-a direct contract with a end user will avoid brokers fee's, however many end users require homogenous and large volumes of recyclable materials. The contracts must also be long term in many cases which it disadvantageous for the government especially is specific requirements cannot be met in the future.

- Open Market Trading- this marketing option requires constant analysis of market price fluctuations and then selling specific amounts of goods to the highest bidder. Open market trading may maximize revenue in the short term especially with items such as scrap metal; however it may be exhaustive for a small staff.

- Market Cooperative-numerous small groups of waste generators may join together to combine their output in an effort to maintain a higher return for the recycled material. The individuals usually must bear the cost of transportation of materials to a central location.

The USACE recommends long term contracts over open market trading especially if price can be agreed on with the broker. Transportation costs are also a key issue in marketing. For example a local end user may offer a lower price for bulk recyclable material that an end user in a nearby state but the cost of shipping the material may outweigh the increase in funds collected.

In an effort to promote recycling military installations should look at the life cycle cost, product manufacturing methods, and raw material input for items purchases, then choose products that are made from post consumer recycled materials.

To provide an effective QRP at military installations it is also important to have standardized accounting and reporting procedures, to ensure that the program is run smoothly and maximize accountability. The Department of the Navy has a required Solid Waste Pollution Prevention Annual Data Summery that (SW P2ADS) that all Naval and 
Marine Institutes that produce more than one ton per day of solid waste must submit. This document provides the formatting and information needed from each Naval Institute, and ensures complete data so that improvements can easily be tracked.(Command 2005) In an effort to guide Army installations the U.S. Army Center for Health Promotion and Preventative Medicine published the "Guide for Developing Integrated Solid Waste Management Plans at Army Installations" that explains the organization and reporting procedures of solid waste programs on Army bases(Medicine 1999). The Air Force also provides documents outlining the requirements for solid waste management plans on bases, and cites reuse, recycling, and composting as the most preferred methods of waste disposal. (USAirForce)

An effective municipal solid waste recycling program must have a well organized, well advertised collection, separation, and recovery system. Significant cost savings are realized when the collection system and collection management are properly implemented. The QRP manager must decided whether to have an in-house collection system or to contract this duty to a private solid waste collection company. The collection system must also be standardized making it easy for the base personnel to participate, and provide continuity when changes in management occur. Separation of recyclable goods from solid waste is another important factor in determining the economic benefits of a QRP at military installations. Mechanical separation system and hand separation by employees may be costly, and efforts to begin separation techniques as soon as the waste enters the recycling stream should be encouraged. Lastly as discussed in the sale of the recyclables effort should be made on the part of the QRP manager to ensure that the resale of recyclables is profitable for the military installations. QRP should work with different end users and brokers, monitor the fluctuation of markets, and be actively involved in seeking new sources for recyclable sale. (Army 2001)

All base personnel including civilians and residents must be involved in the recycling efforts for a QRP to be successful; troop incentive, education, and advertisement are three effective methods. Troop incentive is stimulated by competitions between battalions by awarding the battalion or squadron that annually submits the largest volume of recyclables. Education programs are very useful, particularly on bases that have school facilities. Many military installations educate elementary age children on the benefits of recycling and offer a field trip to the military installation recycling facilities. Advertisement is useful in explaining to base personnel and residents what types of municipal solid waste can be recycled, separation requirements of recyclables, and collection schedules. Many bases include this information in monthly fliers, or post them in offices, commissaries, schools, mess halls, and lounges. (Army 2001)

Because recycling programs represent mature technologies at military bases, a few specific examples are described below.

Sheppard AFB, TX(Inc. 2006)

Sheppard AFB as per Department of Defense Instruction 4715.4 operates a Qualified Recycling Program (QRP) that includes the operation of a government-managed, 
contractor-operated recycling center, operation of a Universal Waste Recycling Center, Construction and Demolition Debris recycling, and composting at the Wichita Falls facility. According to Sheppard AFB Solid Waste Diversion Metric Reports, the base was able to divert over 58,500 tons of waste in fiscal years 2005 and 2006. Sheppard AFB achieved this by implementing recycling and waste reduction programs. It is estimated that the total net benefit from the recycling program was $\$ 549,742$ in fiscal year 2006(pg 24).

Sheppard AFB QRP operates a Recycling Center (RC) on-site, open 5 days a week, with a 24-hour drop off it provides a location for the separation, storage, and processing of recyclable goods. The RC contractor also administers a weekly collection route to collect recyclables from installation facilities and Military Family Housing (MFH). The flowing recyclables are accepted at the RC: cardboard, paper, plastic, aluminum cans, glass, steel (tin) cans, and scrap metal. The government has many mechanical devices to add in the processing of recyclables, they include horizontal balers, a paper shredder, can crushers, and glass crushers.

The QRP at Sheppard AFB also operates a Universal Waste Recycling Operations Center (UWRC), to collect and dispose of wastes that require special handling. Typical waste received at this facility include: aerosol cans, lead-acid batteries, and electronic media, fluorescent lamps, paint, and shop rags. The UWRC helps to divert waste from the total volume and insure that house-hold hazardous waste is disposed of properly.

Sheppard AFB is a participant in the City of Wichita Falls composting program. Green waste generated from grounds maintenance and $\mathrm{MFH}$ residents as well as organic food waste from dining facilities is collected and transported to the City of Wichita Falls composting facility. In 2005 Sheppard AFB diverted over 315 tons of waste to be composted. To dispose of waste in a landfill it costs $\$ 30.80$ per ton of waste, while it costs $\$ 19.80$ per ton to compost the waste. Therefore composting waste will cause a smaller deficit then land filling the same volume of waste.

The managers of Sheppard AFB QRP conduct and document regular economic analysis and market research to insure the best price for materials sold. The market analysis includes the sales price of the commodity, cost of transportation to vendor/government, minimum weight requirements, processing requirements, and quality requirements. Sheppard AFB typically sells recyclable materials to local material handlers because their research has shown a net gain in profits compared to the net profits when recyclables are sold directly to a recycling mill. Usual material handlers include, IESI Corporation, Evergreen Recycling, Ray’s Scrap Metal, and USI International. To receive the maximum sales price for commodities Sheppard AFB segregates compacts, and bales paper, cardboard, plastic, aluminum, and tin cans.

In an effort to increase the amount of recyclables collected, increase the quality of recyclables collected and reduce solid waste disposal costs Sheppard AFB has implemented a variety of recycling outreach programs. General Base awareness is enhanced through fact sheets, newspaper articles, magnets and MFH recycling guides. 
The base also has a user friendly and informative intranet site to provide education resources for base personnel and residents. Sheppard AFB also participates and promotes the following special events: Earth Day, America Recycles Day, Clean Texas, Wichita Falls Clean County, Sheppard AFB Environmental, Safety, and Occupational Health Day.

The success of Sheppard AFB's QRP is dependent of support from all levels in the chain of command. Each level is specifically discussed in section 7.0 Roles and Responsibilities in the QRP Business plan. The QRP provides the chain of command that is typical of many similar programs.

\section{Fort George G. Meade, Maryland}

Fort Meade is a large Army base located in Maryland between Baltimore and Washington DC. There are approximately 50,000 military personnel, civilians, and Department of Defense employees on the base. The National Security Agency (NSA), Army Intelligence and Security Command, the Defense Courier Service, the U.S. Army Field Band, the U.S. Army Intelligence and Security Command, First U.S. Army (East), the Naval Security Group Activity, the 694th Intelligence Group ( U.S. Air Force) and the U.S. Environmental Protection Agency Center are also located on Fort Meade. Fort Meade has many permanent structures including a mall, banks, a post office, medical center, office buildings, and military family housing. Due to the sensitive nature of NSA and other intelligence agency activities solid waste from these locations is not disposed of through the Fort Meade Directorate of Public Works.

Fort Meade generates solid waste with recycling potential from two main sources: residential waste and commercial/institutional waste. Fort Meade has approximately 950 residential housing structures, waste generated from these sites are easily characterized and measured and usually consists of paper, glass, metal, plastics, food wastes, bulky items, furniture, and yard waste. The QRP at Fort Meade requires recyclable materials to be segregated from other wastes for separate collection. As an administrative post Fort Meade collects solid waste from 135 commercial/institutional facilities, the waste generally consists of paper, cardboard, food wastes, clothing/textiles, furniture and packing materials.

Fort Meade takes an active role in compiling with Executive Order 12101 "Greening the Government through Waste Prevention, Recycling, and Federal Acquisition” by developing and implementing an Affirmative Procurement plan. Affirmative Procurement encourages the purchase products and materials with recycled content, less packaging material, or that may be reused. Purchase of the products is guided by EPA documents as well as the Federal Acquisition Regulation 2000, RCRA, and the U.S General Services Administration (GSA) Environmental Products Guide.

The QRP at Fort Meade has been in place since 1991 and is dedicated to the "costeffective waste prevention and recycling of reusable materials in all facilities" (Technologies 2002) Funds received from the QRP are reinvested in the program and 
used for environmental, safety and recycling programs. The QRP at Fort Meade processes the following products:

- Manila folders

- Wooden pallets

- Card stock

- Newspapers and telephone books

- Laser printer cartridges

- Aluminum and steel cans

- 55 gallon drums (unusable)

- Shrink wrap

- Compact disks
- White paper (whole and shredded)

- Fluorescent light tubes

- Brown paper bags and plastic bags

- Plastic soda bottles

- Plastic milk containers

- Clear glass

Fort Meade has one central recycling center on the base; it is open Monday through Friday 7am to 3pm. In addition to this facility there are five recycling drop-off centers located throughout the Fort Meade, items from these centers are collected three times per week and brought to the central recycling center. Curbside pickup is provided for 2,750 on-post residences on a weekly basis, residents are responsible for cleaning and sorting the recyclables. Recycled/recyclable items are collected, sorted, stored and sold on the recyclable market through contracts with vendors that provide pickup, transport, and marketing services. Market research is conducted by the QRP coordinator.

QRP promotion efforts are a crucial component to the success or recycling and the quantity of recyclables collected. Fort Meade distributes a recycling packet to new tenants on the base; this packet includes a recycling brochure to educate tenants about the program, a questionnaire to collect user data, and recycled paper coloring books for children. Other efforts include publicly displayed signs used to inform residents and employees about recycling drop off locations and types of items that can be recycled. The Department of Public Works sponsors two promotional events: America Recycles Day in November and Earth Day in April to promote the program and remind tenants of their responsibilities to participate in recycling efforts. The solid waste management program also recognized the importance of additional training and education for its staff. The Solid Waste Manager and the Recycling Manager are required to attend various conferences and training sessions throughout the year.

Fort Meade's Department of Public Works is responsible for using the DoD's Solid Waste Annual Reporting System to track and report installation solid waste and recycling data. Fort Meade could greatly improve the recycling program by expanding it to accept cardboard recycling. Currently cardboard is collected for recycling but the conveyance system is not in place to package and transport the cardboard to a recycling market. The base also needs to expand and emphasize its Affirmative Procurement Plan to maximize efforts to promote and purchase recycled or recyclable materials. With Fort Meade's continued QRP efforts the base can avoid costs and reduce the amount of solid waste that must be shipped to landfills.

Naval Station Newport RI (NobisEngineeringInc. 2003) 
The Naval Station in Newport RI has approximately 3,500 military personnel and 3,400 civilian persons on base(Defense 2007). The Naval Station Newport estimates that it annually generates over 4,000 tons of solid waste, and recycles approximately $28.42 \%$ of solid waste generated through the stations QRP. The Naval Station consists of 20 plus support commands, education and administration services, commercial support operations, medical services, food services, public works operations, and housing facilities.

The Naval Station has a Solid Waste Collection, Recycling, and Disposal Contract with a Enviro-Safe Disposal Inc, a local waste management company. Solid waste that is not recycled is eventually disposed at the Rhode Island Central Landfill in Johnston, RI. As mandated by the QRP residents in MFH units are supposed to separate recyclable materials before collection on a weekly basis. Items collected include: newspaper, glass, tin, aluminum, plastic, mixed paper, and cardboard. The other larger facilities on the Station dispose of waste and recyclables in large containers that a picked up on a regular basis. The contractor charges fees based on the number of containers picked up and provides a monthly report summarizing total mixed trash, mixed paper, cardboard, and mixed recyclables removed from the base.

The Naval Station Newport implemented a Qualified Recycling Program (QRP) in 1994; this program allows the installation to receive $100 \%$ of the proceeds from the recyclable material sales. There are two methods in which recyclables are collected, station employees and residents can bring scrap metal, aluminum cans, and batteries to a recycling center or the contractor will pick up from designated containers items such as glass, tin cans, plastics, newspapers, cardboard, mixed paper aluminum cans and wood. Weight slips for the designated recyclables are submitted by the contractor on a monthly basis, which aids in the assessment of the volume of materials recycled at the naval station. The Naval Station receives a rebate check for mixed paper and cardboard recyclables; currently there is no market for mixed recyclables such as glass, plastic, and tin cans. The QRP requires that aluminum cans must be emptied, cleaned, and bagged before they are brought to the recycling center. Sales of aluminum occur on a quarterly basis and individuals are reimbursed for their efforts.

The success of the QRP is dependent on the cooperation of key personnel in the base structure including: the Commanding Officers, the Qualified Recycling Board, the Public Affairs Office, the public works department, the Comptroller, Housing Division, Naval Station Environmental Supervisor/Engineer, and Recycling Coordinators. There has been a steady increase in the percentage of waste recycled in the years 2000, 2001, 2002. Nobis (NobisEngineeringInc. 2003) was contracted to assess the progress of the QRP and look for areas of improvement at Naval Station Newport. It was noted in a dumpster survey on January 2003 that large quantities of mixed cardboard we placed in MSW dumpsters rather than dumpsters labeled "Cardboard only". Nobis recommends that 8 cubic yards of dumpster space be added to the Armed Forces Reserve Center at the Naval Station to increase recycling of cardboard. 
Employee training has also been designated as another key factor in reducing MSW volumes at the Naval Station. Pamphlets for employees and new residents are distributed, commercials on the Naval Cable TV channel, and "Plan of the Day" memos are all used to raise awareness about recycling efforts on the base. Paper reduction is another target area for reducing volumes of MSW, techniques include: double-sided copies, circulation lists, reuse of envelopes, and circulation of electronic documents. The Naval Station also strives to procure recycled post consumer goods for to ensure a market for recyclable goods (Clinton 1998).

\section{Landfilling}

Sanitary landfills, which contain liners and soil caps, have been in use since around 1970 . These waste facilities are designed for containment of waste, collection and treatment of leachate, and in some case gas collection for energy production. Some landfills are designed to produce energy from methane generation, although methane production rates from conventional landfills are low. Landfills have a finite life and re-siting of new landfills is increasingly difficult. Many landfills are being moved farther away from where MSW is produced which increases costs of disposal

Much of the waste collected at military installations in the United States is placed in sanitary landfills. Sanitary landfills, in addition to household waste, can also receive non-hazardous sludge, industrial solid waste, and construction and demolition debris. All sanitary landfills must comply with the federal regulations in 40 CFR Part 258 (Subtitle D of RCRA), or equivalent state regulations. Federal sanitary landfill standards include:

- Location restrictions - ensure that landfills are built in suitable geological areas away from faults, wetlands, flood plains, or other restricted areas.

- Composite liners requirements - include a flexible membrane (geomembrane) overlaying two feet of compacted clay soil lining the bottom and sides of the landfill, protect groundwater and the underlying soil from leachate releases.

- Leachate collection and removal systems - sit on top of the composite liner and removes leachate from the landfill for treatment and disposal.

- Operating practices-include compacting and covering waste frequently with several inches of soil help reduce odor; control litter, insects, and rodents; and protect public health.

- Groundwater monitoring requirements_requires testing groundwater wells to determine whether waste materials have escaped from the landfill.

- Closure and post-closure care requirements-include covering landfills and providing long-term care of closed landfills.

- Corrective action provisions - control and clean up landfill releases and achieves groundwater protection standards.

- Financial assurance - provides funding for environmental protection during and after landfill closure (i.e., closure and post-closure care).

- Gas Collection and Treatment - which is either flared or used for energy production 
Landfills are highly engineering containment systems that provide long term storage for MSW. Strict regulation and monitoring have attempted to make these systems more environmentally benign, reducing the impact of the process to the surrounding environment. Landfill operators control leachate, landfill gas emissions, odors, scavenging by birds and wildlife, scattering of material by wind, settling and subsidence.

However, landfills remain environmentally challenging. They contain significant contaminants that can pollute underground aquifers and surface water. Also, landfills harbor large amounts of carbon dioxide, methane, and other toxic chemicals and gases that contribute to greenhouse gases. Landfills are limited waste containment facilities. Eventually landfills reach capacity and many are being closed, capped, and monitored at great expense. Also, because they are so well sealed from water and air interaction, degradation rates are slowed considerably (see Figure 2).

Most modern landfills, to be more cost effective and to increase capacity and operational life time of the facility, have sophisticated recycling programs and therefore divert compostable and re-usable materials from the waste stream before landfilling. However, once a landfill has reached capacity, the very nature of the design preserves the waste mass. Insufficient degradation is allowed to stabilize the waste mass, but sufficient degradation occurs to prevent the re-use of the land. As permitting new landfills become more difficult and as populations increase landfill cannot continue to be relied upon as a primary end point for waste. In additions, many materials now are banned from disposal in municipal solid waste landfills including common household items such as paints, cleaners/chemicals, motor oil, batteries, and pesticides.

Currently landfilling is the most popular form of solid waste management among military installations. This can be for many reasons, but the primary reasons include being a cost effective approach to solid waste management as well as the available land that many bases have provides amiable space for landfill practices. The examples of military landfills below exhibit the benefits and trade-offs.

The Brunswick Naval Air Station (NAS) is approximately 3500 acres and is located near the Atlantic Ocean in southern Maine, just east of Portland. This site has three historical MSW landfill areas which were used from 1945 to 1979. Because these were older landfills, they were not built with the engineering specifications of modern sanitary landfills. Currently, approximately 3,000 people live on the base within a mile of the site areas and the water on site is used for non-potable irrigation and recreational uses. Due to past disposal practices, the soil and groundwater on a portion of the base is contaminated with volatile organic compounds and cleanup actions have be initiated or completed.

Camp Pendleton Marine Corps Base consists 125,000 beautiful acres located on the Pacific coast, situated between Los Angeles and San Diego in southern California. The land represents a large area of undeveloped land between two large urban areas and contains many valuable environmental resources, including coastal wetlands and streams. 
Similar to the Brunswick NAS past disposal practices in on-site unlined or poorly lined landfills have led to the release of contaminants into the environment. Removal of contaminated soils, re-lining and re-capping of the landfills have been necessary at substantial expensive to attempt to remediate the area.

Because of the problems described above with historic landfills, landfill design, construction and operation are highly engineered and regulated. However, despite all engineering efforts, landfills that are filled and capped eventually fail, and because they can contain significant contaminants they are a potential source of contamination to aquifers and surface water (Lee and Jones-Lee 2008). Some of the problems outlined by Lee are a single composite landfill and landfill cover that will eventually fail, allowing rainfall to enter the waste and to mobilize leachate into the surrounding environment. In addition, the monitoring systems generally are inadequate to detect leakage before contaminants reach the groundwater. There also is a lack of funding to monitor retired landfills and with increasing population, homes and business are encroaching on the landfill boundaries, increasing the risk for health effects to the community. All of these problems can be addressed, but they substantially increase the life-time cost of the landfill. Monitoring, buffer zones, stronger liners and caps are all very costly solutions, but, if necessary, should be included in the evaluation of the overall cost of landfilling.

The liner remains the most critical element in restricting the flow of landfill leachate to surrounding groundwater. While wastes are being accepted and landfills are uncapped, landfills located in wet climates generate leachate proportional to the precipitation. In drier climates leachate is produced in active landfills at a lower rate, but still sufficient to pose a threat to surrounding groundwater. Regulations limit the amount of water that is allowed to pool on the bottom liner to 1 foot to avoid stress on the line and the operators manage the leachate by pumping it off-site and treating, usually in a municipal wastewater treatment plant. Once the landfill cover is placed over the wastes, leachate generation stabilizes and the landfill generally stays dry, but this is dependent on the ability of the cover to prevent infiltration of moisture into the wastes through the cover. Studies have shows that the liner, usually constructed of HDPE, probably fails within 4 years of installation (Lee and Jones-Lee 2008).

\section{Methane Emissions from Landfills}

Municipal solid waste landfills are the largest source of human-related methane emissions in the United States, accounting for about 25 percent of these emissions in 2004 (See Figure 3) (USDepartmentofState 2006). Landfill gas (LFG) is created by microbiological processes as solid waste decomposes in a landfill. Since methane is a powerful greenhouse gas, twenty times the heat trapping value of $\mathrm{CO} 2$, landfills are a significant source of emissions. However, methane emissions from landfills also represent an opportunity for an alternative energy source if it can be efficiently captured and converted to electricity or steam. This gas consists of about 50 percent methane $\left(\mathrm{CH}_{4}\right)$, the primary component of natural gas, about 50 percent carbon dioxide $\left(\mathrm{CO}_{2}\right)$, and a small amount of non-methane organic compounds. Government sponsored programs, such as the U.S. EPA's Landfill Methane Outreach Program (LMOP), provides assistance 
and partnership programs dedicated to the promotion of the use of landfill gas as a renewable, green energy source.

Landfill gas is extracted from landfills using a series of wells and a blower/flare (or vacuum) system. This system directs the collected gas to a central point where it can be processed and treated, depending upon the ultimate use for the gas. From this point, the gas can be simply flared or used to generate electricity, replace fossil fuels in industrial and manufacturing operations, fuel greenhouse operations, or be upgraded to pipeline quality gas.

Electricity for on-site use or sale to the grid can be generated using a variety of different technologies, including internal combustion engines, turbines, micro-turbines, Sterling engines (external combustion engine), Organic Rankin Cycle engines, and fuel cells. The vast majority of projects use internal combustion (reciprocating) engines or turbines, with micro-turbine technology being used at smaller landfills and in niche applications. Certain technologies such as the Sterling and Organic Rankin Cycle engines and fuel cells are still in the development phase.

Currently military installations have been looking at using methane released from landfills to help power their business operations. Hill Air Force Base (AFB), located near Salt Lake City, is the first Federal facility with its own dedicated landfill-gas power plant (Price and Abbot 2002). Since Hill AFB was located next to a small landfill, it became the designated recipient of the MSW produced methane. To complete the project, 3,000 feet of pipeline was run to the AFB. The small landfill delivers 400 to $500 \mathrm{cfm}$ of methane and is able to provide $3 \%$ of the base's electricity needs or $1320 \mathrm{~kW}$ of power annually. Benefits have included replacing coal generated electricity thereby reducing annual emissions by 5000 tons of $\mathrm{CO}_{2}, 2.8$ tons of $\mathrm{CO}, 19$ tons of $\mathrm{SO}_{2}$, and 5.5 tons of $\mathrm{NO}_{2}$. In addition, the base was able to use the installation of the diesel engines and pipeline as a training opportunity for the AFB personnel.

There exist some drawbacks of methane recovery from landfills. Methane generation may be unpredictable and variable; production starts within a year of landfill filling and capping, and peaks 5-7 years after completion (Barlaz, Ham et al. 1989). Methane production eventually slows to a fraction of the peak and is not longer usable for energy

production. Substantial infrastructure is needed to collect the methane from the landfill and convert it to electricity, and some clean up is needed in the gas stream before it can be used in a conventional boiler or heat generation unit. Also, since landfills are built away from urban areas where power generation is needed, transfer of the electricity and/or methane gas may not be cost effective.

\section{Bioreactor Landfills}

Bioreactors are municipal solid waste landfills that are designed to quickly transform and degrade organic waste. The increase in waste degradation and stabilization is accomplished through the addition of liquid and, in some cases, air to enhance microbial processes. Bioreactors are a new approach to landfill design and operation that differ 
from the traditional "dry tomb" municipal landfill approach described above. Bioreactors use a design similar to sanitary landfills but enhance biodegradation by recycling leachate. Added water (gray water or sewage can be used) increases the rate of degradation by transferring nutrients and optimizing the growth conditions and therefore and metabolism of methane producing bacteria(Borglin, Hazen et al. ; Barlaz, Ham et al. 1989). Increased degradation rate produces more methane and increased degradation rate produces more settling. Aerobic landfills operate by adding air, either by pushing or pulling it through the waste pile, anaerobic landfills operate by simply recycling the leachate. Aerobic operation will greatly enhance degradation rates. However, aerobic landfills do not produce methane. Rapid settling will provide more capacity for waste disposal (see Figure 4) (Borglin, Hazen et al.).

At stated previously, in 1976, the US government passed RCRA, which outlined specific requirements for landfilling which laid out the requirements for landfills to have a liner, a leachate collection system, and an impermeable cap. While this has greatly diminished the leaching of toxic chemicals from landfills to the environment, it has also preserved waste in the landfills (the dry tomb effect). The available space for landfills is decreasing rapidly and the current landfills are near capacity. In addition, in RCRA designed landfills, the waste is only partially stabilized, maximum settlement has not occurred and methane production continues, precluding re-use of the land. 230 million tons of municipal solid waste is produced in the US annually, and $57 \%$ of this is buried in landfills (Hazen, Borglin et al. 2001).

Landfill stabilization is defined as a state in which negligible gas is being produced, leachate does not constitute an environmental hazard, and maximum settlement has occurred (Anex 1996; Koerner and Soong 2000). Studies have shown that the recirculation of leachate in Municipal Solid Waste (MSW) will increase the degradation rate and methane production rate while decreasing the contaminants in the leachate. There have been numerous projects studying leachate recirculation, mostly on a small scale (Stessel and Murphy 1992; Reinhart and Townsend 1997; O’Keefe and Chynoweth 1999; Pohland and Kim 1999). Few studies have shown the impact of aerobically treating the waste on a large scale (Reinhart and Townsend 1997; March, Hudgins et al. 2001). Recent studies have focused on waste to energy facilities, which utilized the MSW to produce methane, which is converted to electricity. The problem is that methane production is difficult to control and can range from 1-50\% (Barlaz, Ham et al. 1989). The unpredictability mixed with the costs involved with building the extraction and purifying systems makes this type of facility only viable in larger communities. In the remaining landfills where methane is not collected for energy, methane is slowly leaked into the atmosphere where it acts as a powerful greenhouse gas, trapping heat 21 times more efficiently than carbon dioxide(Borglin, Hazen et al.).

In MSW landfills where methane recovery is not feasible, aerobic treatment has several important advantages. Some benefits of aerobic treatment are that humic material could be recovered for soil improvement, considerable volume reduction could be achieved, recyclable materials could be extracted, lining system could be repeatedly inspected after mining to insure integrity, and coincident treatment of leachate before discharge (Stessel 
and Murphy 1992). It also would lead to negligible methane production and low concentrations of contaminants in the leachate.

Operationally, if the bioreactors were treated in parallel and in similar manner to sewage treatment systems a sustainable system could be developed. Waste could be mixed with sewage solids and watered with sewage liquids. Initial anaerobic stages would produce methane and, after methane production slows, waste reduction could be achieved through aeration. Decomposed waste could be mined for metals and plastics not separated at the source, and used for landfill cover.

There are some problems with the operation of landfill as bioreactors that have limited their popularity. Increased technical knowledge and engineering are needed to maintain the systems, especially during settling of the waste mass. Piping and leachate collection systems may fail as the waste subside, and concerns about slope stability and maintaining liner integrity under the increase stress of recirculation and a wetter waste mass pose serious engineering problems. For methane production by anaerobic bioreactors, the landfill will need facilities to capture the methane and convert it to energy. For aerobic treatment, the cost-benefit analysis when considering energy and water requirements for leachate recycling and/or aeration may make the landfill non-economical, especially in dry climates. Finally, both bioreactor landfill types release greenhouse gases and other air pollutants which need to be monitored and controlled. These pollutants will eventually be released over the lifetime of the landfill, but increased degradation rates will greatly enhance the rate of release of these contaminants. With the world looking to solutions for carbon sequestration, release of trapped carbon from capped and sealed landfills is a less attractive solution. As a result of these issues, several previous attempts at starting landfill bioreactors have failed due to odor complaints, vector problems, or operational difficulties.

\section{Composting}

Collection and degradation of green and food waste systems have been established at several military bases (EPA 1997; Hardcastle 2003; Bost 2004; Tai 2007; Young 2007) and have been shown to be an effective way to reduce the amount of waste entering landfills.

Compositing is method that reduces volumes of organic solid waste through biological decomposition. It has proven useful in reducing volumes of yard waste and natural debris sent to landfills, but can be applied to organic household solid wastes such as food scraps and paper. (EPA).Composting is a mostly aerobic process in which bacteria, actinomycetes, fungi, protozoa, worms, and larvae consume decomposable nutrients such as proteins, carbohydrates and sugars. The technology is similar to the bioreactor landfill but it is applied on a smaller scale to separated landscaping and food waste streams.

Because composting is a biological process it behave exponentially, starting with a lag phase during which bacterial populations are developing and growing, followed by an active growth phase during which the most readily degraded organic material is 
consumed, follow by a maturation phase when surviving bacteria subsist on harder to metabolize food sources and fungi play a larger role. Worms, insects and other larger animals aid in aeration and turning of the compost. In the active growth phase, the temperature may rise around $60^{\circ} \mathrm{C}$, helping to reduce numbers of enteric and pathogenic organisms.

Microbial activity is key to the decomposition of waste, and while these organisms are present throughout waste life cycles there are certain parameters that must be met to ensure maximum composting rates. Composting is aerobic therefore sufficient oxygen is required; this can be achieved by turning or aerating composting piles on a regular basis. Particle size is important because small particles have larger surface areas per volume which aids in the microbial process. However, if the particles are too small aeration of the pile is difficult. Macronutrients such as carbon, nitrogen and phosphorus, and potassium are required for energy, synthesis or proteins, reproduction, and metabolism. For optimum degradation these must be available in sufficient concentration, specific forms, and proper ratios, typically carbon and nitrogen are the limiting factors (EPA 1997). Moisture content (water will typically need to be added) and interstitial volume must be controlled to ensure at least 50\% moisture content and appropriate spacing between particles to allow for air (EPA 1994; Cheremisinoff 2003). Temperature must be controlled, as microorganisms do not propagate at low temperatures (less than $20^{\circ} \mathrm{C}$ ) and some microorganisms die at temperatures about $60^{\circ} \mathrm{C}$. Lastly $\mathrm{pH}$ must be controlled as microorganisms and fungi usually do not operate in extreme acidic or basic conditions.

Compost requires space for the composting facilities and some education of personnel to operate. It also requires a system for collection of the food waste, or separation of the organic waste from the collected waste stream. Also to be considered is the fuel and water that will be consumed during the collection, degradation, and dispersal of decomposed waste. Many larger systems will require blowers to operate on a intermittent basis to help the aeration processes, and weekly turning of the compost mass may be required. However, if successful, compost is an excellent method of reducing waste volume and the resultant product replenished necessary nutrients into soil, providing an opportunity for improved stewardship of DOD facilities (Tchobanoglous and Kreith 2002)Waste characterization is an important step in determining the optimal collection method for any community. A waste characterization study will allow a military installation to determine how much solid waste could be diverted for composting, what types of waste is generated, and seasonal variances in the types of compostable waste. The percentage of compostable waste will also differ from source to source (homes vs. industrial settings). The waste characterization study will determine the size and frequency of collection operations.

Separation is another aspect of a successful composting program that must be taken into consideration. In grounds-keeping and landscaping processes it is easy to keep compostable waste separate from other solid wastes, however industrial and residential sources are not as simple. It is up to the military installation to determine if it is easier to separate compostable materials at the source or after the collection system. Recent economic and recovery analysis studies show that with the development of sophisticated 
material recovery facilities, single source collection is more efficient at green waste recovery (Herbert 2008; Weinick 2008).

End product compost material can be used on site or sold for beneficial use to the surrounding community to help offset costs (Weinick 2008). Military installations that have composting abilities on site can use the composted material for erosion control, turf remediation, and general landscaping applications. For example, the Army used composted material at U.S. Army Golf Course Operations Division at Fort George Meade, Maryland, to mitigate soil compaction, erosion, and turf disease problems on the golf course. The golf course manager estimated that the $\$ 50,000$ / year in maintenance costs were saved by using compost (EPA 1997). Ft Lewis also successfully set up a compost operation that benefits the base and the surrounding community (Young 2007) Composting helps lower operation costs by waste reductions, and provides and on-site disposal method which reduces the amount of waste that is collected and transported off site. In addition it produces a valuable product that can be used on site or sold to offset costs. (Porter 2002)

\section{Incineration}

MSW can be burned in special incinerators using the resulting energy to produce steam or electricity. The US now burns 15 percent of its solid waste - 14 percent in waste-toenergy plants and the rest in conventional incinerators. Burning waste substantially reduces the amount of trash going to landfill. With recent energy demands causing energy producers to look for alternative fuel, burning trash appears to be a readily available source. Some of the drawbacks of incineration are (1) some communities, to keep incinerators profitable, burn recyclable waste and may ultimately hamper recycle programs; (2) waste-to-energy plants emissions cause air pollution (dioxins, heavy metals) issues and monitoring and enforcing regulations is expensive; (3) 20\% residue needs to be landfilled (4) incinerators are 'landfills in the sky' and release contaminants and greenhouse gases to the atmosphere.

Incineration is a common practice used by both public and private sectors to reduce the volume of solid waste that is landfilled. Incineration can be a cost effective, environmentally safe process, while decreasing the amount of waste that is landfilled. General benefits of incineration include a reduction in the volume and mass of wastes (up to $90 \%$ of the volume and up to $75 \%$ of the mass), destruction of some wastes and detoxification of others, rendering them more suitable for final disposal, destruction of organic components of biodegradable waste that may generate landfill gas, also the recovery of energy from combustible wastes.

Incineration is an engineered process using controlled flame combustion to thermally degrade waste materials. Incineration is the controlled burning or combustion of various types of waste. MSW has an average heat value of 8 to $12 \mathrm{MJ} / \mathrm{kg}$, as compared with 19 $\mathrm{MJ} / \mathrm{kg}$ for dry wood, $15 \mathrm{MJ} / \mathrm{kg}$ for lignite or $22 \mathrm{MJ} / \mathrm{kg}$ for steaming coal. Plastics have an average heat value of $33 \mathrm{MJ} / \mathrm{kg}$. Wet compostable material is in the range of 4 to 6 $\mathrm{MJ} / \mathrm{kg}$, while for comparison, natural gas has a value of about $39 \mathrm{MJ} / \mathrm{Nm}^{3}$ (56 
MJ/kg)(Porter 2002; Cheremisinoff 2003). Typical plants burn 200-3000 tons MSW/day (Tchobanoglous and Kreith 2002). Incinerators, when properly operated, can produce energy in the form of steam and heat that can either be used sold for profit or can be converted into useful forms of energy to supply to military institutions. Incineration occurs at very high temperatures, and these extreme temperatures decimate the presence of any hazardous bacteria present in the waste ash produced. The waste ash that is the byproduct of combustion is usually used in construction process; about ten percent of the total ash formed in the combustion process is used for beneficial use such as daily cover in landfills and road construction(Siritheerasas 2000).

There are six basic types of incinerators used worldwide:

- Municipal Waste Combustors

- Hospital/Medical/Infectious Waste Incinerators

- Commercial and Industrial Solid Waste Incineration Units

- Institutional Waste Incinerators

- Hazardous Waste Incinerators

- Manufacturing Waste Incinerators

- Industrial Boilers and Furnaces

Basic municipal waste incinerators are rated based on the amount of waste they can process per day. Municipal waste incinerators can burn household, commercial, and/or institutional waste. Small municipal waste incinerators can burn between 40 tons and less than 250 tons of waste per day and very small municipal waste incinerators burn less than 40 tons of waste per day. In 2000 the EPA finalized the guidelines and standards for large and small municipal waste incinerators. These guidelines were put in place to help States develop regulations to control incinerator pollutants and emissions. Incinerator emissions regulations require federal, state, and local permits and must meet all applicable standards. Some states, such as California, do not permit the use of incinerators because they cannot meet California's strict air emissions requirements.

As an example, the follow list is all the current federal regulations that have to be followed for incinerator permits.

- CFR Title 40 - Chapter I - Subchapter C- Part 60 - Air Programs

- Pollution Prevention Act of 1990

- EO 12856, Federal compliance w/ pollution prevention act

- Clean Air Act (CAA) (42 USC §7412), Section 111

- Resource Conservation and Recovery Act (RCRA) (42 USC §§ 6901-6992k)

- Toxic Substances Control Act (TSCA) (15 USC §2601)

- Comprehensive Environmental Response, Compensation, and Liability Act (CERCLA), referred to as Superfund (42 USC §9601)

- National Ambient Air Quality Standards (NAAQS)

Under the Resource Conservation and Recovery Act (RCRA), states must adopt regulations at least as strict as those required by the new municipal solid waste incinerator performance standards and guidelines. Current regulations for emissions of both large and small incinerators are shown in Table 6.

Page $\mid 21$ 
The main pollutants of concern from incinerators are particulates (ash - bottom ash and fly ash and unburned carbon particles), acid gases (sulfur dioxide and hydrogen chloride), nitrogen oxides, and carbon monoxide. Other pollutants are produced from the burning process, including the carcinogens dioxin and furan, and heavy metals from batteries and electronic sources.

Particulates are produced in the furnace during the combustion process and even with modern particle filtering of the flue gases, a fraction of these are emitted to the atmosphere. Baghouse filters are only specified to capture 65-70 \% (in weight) particulate smaller than $2.5 \mu \mathrm{m}\left(\mathrm{PM}_{2.5}\right)$ (EPA 2005). $\mathrm{PM}_{2.5}$ is suspected to be linked to infant mortality in the UK and can cause lung disease in adults(Committee on Health Effects of Waste Incineration, Board on Environmental Studies and Toxicology et al. 2000; EPA 2005).

'Dioxins' and 'furans' are generic terms for a group of more than 200 individual chemical compounds. They are produced during combustion of organic materials such as plastics. These compounds are persistent in the environment and accumulate in magnified concentrations as they move up the food chain, concentrating in fat, notably in breast milk. Interacting directly with DNA through a receptor-based mechanism, dioxin also acts as an endocrine disruptor with adverse effects on reproduction, development, and the immune system.

Historically, health concerns raised by incineration focused on communities living near the incinerator. Potentially exposed populations are the plant operators and people who live and work nearby the incineration plants, although the persistence of organic and heavy metal pollutions could have an effect on the environment and health for several generations.

Although greenhouse gases are released during all incineration processes, the U.S. EPA states that the use of incineration processes, as compared to landfilling will help to reduce the production of greenhouse gases otherwise produced from landfilling municipal solid wastes.(EPA 2008) The reduction comes because methane from landfills is not released into the atmosphere; incineration replaces some $\mathrm{CO}_{2}$ emissions from fossil fuel combustion, and because incineration processes are efficient at recovery of ferrous metal and this recycling and recovery avoids the relatively high $\mathrm{CO}_{2}$ emissions from mining activities. However, a recent Eunomia report (Hogg 2006) found that incinerators contribute to climate change due to their $\mathrm{CO}_{2}$ emissions, and that existing incinerators were less energy efficient than emerging technologies.

In considering the MSW incineration option, decision makers must weigh the benefits of incineration against the significant capital and operating costs, potential environmental impacts, and technical difficulties of operating an incinerator. When operated properly by well-trained employees, modern waste incinerators pose little risk to public health. But older designs, human error, and equipment failure can result in higher-than-normal, shortterm emissions that need to be studied further. Prevention, waste minimization, reuse 
and recycling of waste should all be preferred to incineration. Supporters of zero waste consider incinerators and other waste treatment technologies as barriers to recycling and separation beyond particular levels, and that waste resources are sacrificed for energy production. Building and operating an incinerator requires long contract periods to recover initial investment costs, causing a long term lock-in. Incinerator lifetimes normally range from 25-30 years, many think that incinerators are not very economical in this day and age with other ways that waste can be reduced.

\section{Emerging Technologies}

\section{Pyrolysis}

Pyrolysis is a developing technological improvement to conventional incineration. Pyrolysis is heating in the absence of oxygen, although in practice some oxygen is present. The process produces gas, a small volume of liquid, and a solid residue. Major applications of this technique are destruction of organic volatile compounds, pesticide, and fuel containing soil. Some systems use molten salt oxidation (MSO) to help transfer heat and removed particulates, allowing operation at a lower temperature, and reduced fugitive emissions of radionuclides than may be present in the soil. The advantage of pyrolysis over conventional incineration is lower emissions of particulates and other toxic gases (although limited knowledge is available on the efficiency of the combustion of PCBs and dioxins) and improved energy recovery (Cheremisinoff 2003). Pyrolysis is not effective in reducing toxicity due to heavy metal contamination. Pyrolysis systems can handle a wide variety of waste streams and released heat can be converted to sustain the process. New systems called vacuum pyrolysis allow for the recovery of some fuel components from the incineration of tires. (Murugan, Ramaswamy et al. ; Cheremisinoff 2003; Malkow 2004; Ma, Lin et al. 2006). Systems have been successfully used for MSW on Naval ships, and portable systems are used with deployed US military. A new system, named the Tactical Garbage to Energy Refinery (TGER) uses pyrolysis to convert incoming waste to energy (Provence 2008).

\section{Plasma Arc Gasification}

Plasma arc gasification is the latest development in pyrolysis of MSW and conversion of waste to energy. This technology is very promising because it can take any source material and convert it to elemental constituents, thereby removing problems of release of toxic organic compounds into the environment because the high temperature $\left(4,000^{\circ} \mathrm{C}\right.$ to over $7,000^{\circ} \mathrm{C}$ ) of the plasma arc greatly reduces the potential for undesirable byproducts (such as dioxins and furans). Plasma treatment can accept waste without pretreatment of separation. The organic matter in wastes produces gas products with heat and fuel value which are sufficient to run the plant and produce enough energy to offset infrastructure costs. The residue can be a vitrified slag, blown wool (similar to glass wool) or a gravellike product, all of which a significant re-use potential in road and building construction projects (Park 1997; Vaidyanathan, Mulholland et al. 2007; Cicero 2008). New applications of this technology are insertion into boreholes for slope stabilization and in situ treatment of landfill and toxic waste. If successful, this process would provide a 
solution for stabilization and land-reuse of post-closure landfill sites. Major hurdles to overcome before the widespread adoption of this technology are high cost installation and start up cost as well as emissions of $\mathrm{CO}_{2}$ and NOX gases. Novel solutions to this problem include injecting the gases into bioreactors to catalyze microbial conversion of biofuel feed stocks to ethanol (Cicero 2008).

\section{Discussion}

The technologies described above that can be used for sustainable waste reduction all have benefits and drawbacks. When setting up an ISWMP, each installation will have to look for the options available in the area they are located. However, depending on the size of the installation related to the size of the community, the installations may have a large impact and influence on the waste stream and can facilitate and support the creation of markets for recycling, compost, or waste to energy plants. In doing this they will create local resources and jobs for the community and aid in the overall waste production plan.

To aid in comparison of the technologies, Table 7 was prepared. Each technology was scored on a scale of 1 to 5 on a variety of metrics, with a score of one representing low sustainability and a score of 5 representing high sustainability. Once complete the total was compiled for each resulting in an overall sustainability score. Note this scaling was done with the application of these technologies at military installations.

The first metric that was evaluated was whether the technology was ready to use and implement. Source reduction, landfilling and recycling are mature waste handing methods which are in use today and are generally available in all parts of the country, so they received high marks for usability. Incineration and pyrolysis have limited availability so they have lower values. Composting has only been tried at a few installations, but with the low infrastructure requirements it can be available with a fairly short planning time. Landfill bioreactors and plasma-arc technologies have very limited capacity for usage at this time.

Ease of use for the waste producer is a key factor in the success of sustainable solid waste management. Landfilling, incineration, bioreactors, pyrolysis, and plasma arc are all processes that occur after collection, so they will not change the method in which the producer handles waste. Source reduction and recycling all require some thought on purchasing decisions and handling of waste, and for some this is a barrier to participation. Advance material handling facilities that work on single stream waste separation will increase the participation and ease of use of recycling. Financial incentives such as lower prices for bulk purchasing, education, and improvement of packaging design will increase the sustainability of source reduction. On site composting of waste generally takes some dedication on the part of the installation, as the waste will need to be monitored, aerated, and either distributed on site or sold once mature. This will require more investment of time which will reduce the overall long term or year to year sustainability of this effort. 
The next two metrics, ease of use for the operator, and technical skills required to operate, are closely related but have some minor differences. For example, once implemented, recycling and source reduction by procurement officers is straightforward. But developing recycling source reduction plans, finding markets for recyclables, and updating procedures require more technical and analytical skills. For landfill and landfill bioreactors, the technical skill required to manage and design these systems are fairly high, but daily use of the landfill is relatively straightforward. Operationally, all waste management, post collection, does take some technical skill and industrial knowledge of processes and marketing of either energy or recyclable, but since this is a sector where the industry can provide training and employment as long as it is an economically viable solution the technical knowledge needed should be sustainable.

Looking at infrastructure needs creates a division between source reduction, recycling, and composting as compared to landfilling, incineration, bioreactors, pyrolysis, and plasma arc technologies. Source reduction does not take any additional facilities and reduces the need for landfilling. Recycling requires collection, separation, and processing facilities, but this somewhat offset by lower need for landfilling. Landfilling represents a permanent loss of land use, and bioreactors, while they may increase the capacity for the system, require equal or greater infrastructure investment than sanitary landfills. The three waste-to-energy processes require investment in expensive plants and permitting processes, as well as energy production machinery, which make the building of these plants a major infrastructure development process, limiting their availability for sustainable waste solutions.

Land use is another consideration for sustainability. In this analysis was considered not only military land use, but land use in the surrounding community. Source reduction has no land use requirements and recycling has limited needs. Issues with land use from waste-to-energy do not stem from overall footprint, but from issues due to health concerns with located near population centers and balancing that with fuel costs to transport waste longer distances. Composting uses land area for the process but requires no permanent installation, but there may be considerations due to the fact that composting will most likely be performed on site, so depending on the installation this may be a factor in considering this technology. One of the main drawbacks of landfilling is nonrenewable land use, resulting in a low sustainability factor.

Greenhouse gas emissions were considered separately because of growing evidence of global climate change. If carbon credit legislation is passed, increased scrutiny will be placed on sources of carbon dioxide and methane into the environment and increasing interest will be given to waste reduction and recycling, as waste decomposition accounts for a significant portion of carbon emissions in the US(Hogg 2006; USDepartmentofState 2006). All waste-to-energy plants emit carbon dioxide. However, plasma arc technology promises a cleaner gas stream than incineration and to a lesser degree pyrolysis, and if the flue gas is use to stimulate biofuel production the carbon footprint of this technology will decrease. Due to the large methane emission from landfills it has very low sustainability in terms of carbon usage. Even though tons of carbon are stored in landfills (carbon 
sequestration), other considerations (land use, leachate) remove this from consideration of a sustainable solution for carbon storage.

RCRA legislation has greatly decreased the environmental damage from landfills but for the long term, environmental damage due to leakage of leachate into groundwater can be a serious threat. One advantage of the bioreactor landfill is treatment of the leachate during recirculation so if leakage occurs the leachate is more environmentally benign. Release of toxic metals, dioxin, and furans remains a major concern when evaluating incinerators. Recycling, due to potential of pollution from industrial processing of postconsumer waste excessive water use, was given a lower sustainable score.

As far as market acceptance, most technologies are relatively easy to use and operate, and people are willing to accept them as part of the overall process, as long as they are not living next door to the landfill, recycling plant, or incinerator. The NIMBY (not in my back yard) syndrome causes decreased acceptance of some technologies. However, concerns about health can be balanced by waste-to-energy products which provide local energy source. Bioreactor landfills were given a low rating, because they are generally thought of as a public nuisance and difficult to operate. This technology, if it is to survive, needs to improve public perception.

The next metric, waste reduction, is a fairly straight forward analysis with landfills getting a low score and incinerators, source reduction, and recycling being more sustainable. The last metric, energy production, was added because this is the major advantage of the waste-to-energy technologies and as energy prices increase, interest in these technologies will also increase. If military installations are sufficiently large they may consider gas arc systems that will dispose of waste, including toxic or munitions waste, and also provide energy for on-site needs. As for overall cost, this is hard to measure, because you have to consider not only the actual costs, but the long term benefits as well as environmental costs. There are initial infrastructure needs, but also monitoring, transport, and clean up costs. In addition, there also may be profits due to energy production, sale of recyclables, and cost savings due to waste reduction.

\section{Summary and conclusions}

Overall landfilling and landfill bioreactors received the lowest score for sustainability; although bioreactors have enhanced environmental benefits their difficulties in social acceptance and operation reduce the attractiveness of the solution.

Plasma Arc gasification and Pyrolysis received low scores, but as the technology is proven further this approach may be considered a solid sustainable solution, and could be considered as either a bio- or alternative- energy source or a waste recycling system. The ability to reuse the byproducts of the combustion, as well as to combust a wide variety of waste streams, may make the relative high price of installation more economically viable. In addition if the plasma could be use to gain energy from closed landfill this could provide a reliable alternative to fossil fuel energy. 
Overall, source reduction is the most sustainable solution, but since zero consumerism is not achievable, it will remain only as part of the answer to waste minimization on military base. Recycling can be implemented as long as personnel are educated on the benefits of the practices, the base has convenient receptacles or contracts with a collection agency with a materials separation facility, and there exists local markets for recyclable materials. Composting is an excellent way to recycle green and food waste and divert from landfill, increasing overall diversion rates and providing high quality mulch and soil amendments for sale or use for onsite landscaping. Waste to energy can be solution for non-recyclable, non-combustible, non-reusable resources, as long as it does reduce recycling rates and can be reliably operated so it is safe to human health and the environment.

As stated in the introduction, options for waste disposal for each military installation is regionally dependent because of variations in climate, and size of population, traffic, noise, and local regulations. Each base will be required to analyze available options and developed the most cost effective and efficient plan. However, due to the influence the base may have on the surrounding community and because of available resources, DOD installations should take a primary role in developing promoting new technologies and support the building of infrastructure to increase the long term stability of base operations and readiness of the military.

Acknowledgment: This work was partially supported by the Director, Office of Science, Office of Biological and Environmental Research, Environmental Remediation Sciences Program, of the U.S. Department of Energy under Contract No. DE-AC02-05CH11231.

\subsection{References}

AirForce (1994). Air Combat Command Solid Waste Program Management Guidance. A. Force: 6.

Anex, R. P. (1996). J. Env. Eng 122: 964-974.

Army (2001). "Army Recycling Lessons Learned." Public Works Technical Bulletin 42049-12: 28.

Army (2001). "Direct Sale of Recyclables." Public Works Technical Bulletin 420-49-18: 77.

ASTSWMO (2007). ASTSWMO 2006 Beneficial Use Survey Report. A. o. S. a. T. S. W. M. Officials.

AustralianGovermentDOD (2004). "Deployed Force Waste Management."

Barlaz, M. A., R. K. Ham, et al. (1989). " Mass-Balance Analysis of Anaerobically Decomposed Refuse." Journal of Environmental Engineering 116(6).

Basham, D., K. Ferguson, et al. (2004). "Solid Waste Disposal, Naval Facilities Engineering Command, Unified Facilities Criteria." 1-139.

Borglin, S., T. C. Hazen, et al. "Comparison of aerobic and anaerobic biotreatment of municipal solid waste." J. Air and Waste Management Assoc 54: 815-822.

Bost, J. (2004). "Composting solid waste in overseas contingency operations." 
Cheremisinoff, N. P. D. (2003). Handbook of Solid Waste Management and Waste Minimization Technologies. San Francisco, Butterworth-Heinemann.

Cicero, L. (2008). Plasma Arc Gasification. Sustainability of Solid Waste Management. San Francisco, CA.

Clinton, W. (1998). Executive Order 13101—Greening the Government Through Waste Prevention,Recycling, and Federal Acquisition. O. o. t. President, Federal Register.

Command, U. S. N. F. E. (2005). "Fiscal Year 2005 Solid Waste Pollution Prevention Annual Data Summary." 73.

Committee on Health Effects of Waste Incineration, Board on Environmental Studies and Toxicology, et al. (2000). "Waste Incineration and Public Health." 189-190.

Defense, D. o. (2007). "Base Structure Report Fiscal Year 2007 Base Line." 221.

DefenseEnvironmentalPrograms (2006). App V: Solid and Hazardous Waste Pollution Prevention, FY 2006 Annual Report to Congress. D. o. Defense.

DOD (2007). Base Structure Report Fiscal Year 07 Base Line. I. a. E. D. o. D. Office of the Deputy Under Secretary of Defense: 221.

EPA (1994). "Composting Yard Trimmings and Municipal Solid Waste." Office of Solid Waste and Emergency Response: 151.

EPA (1997). "Innovative Uses of Compost Bioremediation and Pollution Prevention."

EPA (1997). "Innovative Uses of Compost Composting of Soils Contaminated by Explosives ".

EPA (1997). "Innovative Uses of Compost Erosion Control, Turf Remediation, and Landscaping."

EPA. (2008, January 30, 2008). "Solid Waste Combustion/Incineration." Retrieved February 15, 2008, from http://www.epa.gov/garbage/landfill/sw_combst.htm.

EPA. (2008, 1/8/08). "Source Reduction and Reuse." from http://www.epa.gov/garbage/sourcred.htm.

EPA, G. (2005). Waste Incineration - A Potential Danger?, .

Hardcastle, W. (2003). "Assessment of composting feasibility at Army Installations." CHPPM Technical Information Paper \#38-001-1203.

Haselbach, L. (2008). The Engineering Guide to LEED-New Construction: Sustainable Construction for Engineers, U.S. Green Building Council's LEED-NC.

Hazen, T. C., S. E. Borglin, et al. (2001). Experimental Investigation of Aerobic Landfill Biodegradation. Earth Sciences Division Annual Report. Berkeley, CA, Lawrence Berkeley National Laboratory.

Herbert, E. (2008). Systems approach to municipal solid waste collection. Sustainability of Solid Waste Managment. San Francisco, CA.

Hogg, D. (2006). A Changing Climate for Energy from Waste? Final Report for Friends of the Earth. Cotham, U.K., Eunomia Research \& Consulting Ltd.

Inc., T. T. (2006). Sheppard Air Force Base Qualified Recycling Program (QRP) Business Plan. n. C. E. Squadron: 97.

Koerner, R. and T. Y. Soong (2000). " Leachate in Landfills: the Stability Issues." Geotextiles and Geomembranes 5.

Lee, F. and A. Jones-Lee (2008). Flawed Technology. 
Ma, R.-H., Y.-C. Lin, et al. (2006). "The study of thermal pyrolysis mechanisms for chlro organic compounds in electric cable and medical wastes." Journal of Analytical and Applied Pyrolysis 75: 245-251.

Malkow, T. (2004). "Novel and innovative pyrolysis and gasification technologies for energy efficient and environmentally sound MSW disposal." Waste Management 24(1): 53-79.

March, J., M. Hudgins, et al. (2001). \#47639. Berkeley, CA, Lawrence Berkeley National Laboratory.

Medicine, U. S. A. C. f. H. P. a. P. (1999). "Guide for Developing Integrated Solid Waste Management Plans at Army Installations." 56.

Murugan, S., M. C. Ramaswamy, et al. "The use of tyre pyrolysis oil in diesel engines." Waste Management In Press, Corrected Proof.

Navy (February, 1999). Navy Environmental Quality Fact Sheet on Solid Waste Management practices. Department of the Navy Environmental Protection. C. o. N. O. United States Navy.

NobisEngineeringInc. (2003). Solid Waste Management Plan Naval Station Newport. E. P. D. (N8N). Newport, RI: 51.

O’Keefe, D. M. and D. P. Chynoweth (1999). "Influence of Phase Seperation, leachate recycle and aeration on treatment of Municipal Solid Waste in Simulated Landfill Cells." Bioresource Technology 72.

Park, H. S., et. al (1997). Medical Waste Treatement by Plasma system Novosibirsk, Akademgorodok, Russia, 3rd International Workshop "Thermal Plasma Torches and Technologies"

Pohland, F. G. and J. C. Kim (1999). "In Situ Anaerobic Treatment of Leachate in Landfill Bioreactors " Water Science Technology 40.

Porter, R. (2002). The Economics of Waste. Washington,D.C., Resources for the Future.

Price and Abbot, G. (2002). Hill Air Force Base Landfill Gas to Energy Biogas Case Study.

Provence, D. (2008). Tactical Garbage to Energy Refinery. Sustainability of Solid Waste Management. San Francisco, CA.

Reinhart, D. R. and T. G. Townsend (1997). Landfill Bioreactor Design and Operation. New York, Lewis Publishers.

Services, E. (2005). Air Force base cuts costs with methane generation. 2008.

Siritheerasas, P., Lawrence,D. (2000). "Incineration of MSW using Biomass as a Secondary Fuel."

Stessel, R. I. and R. J. Murphy (1992). Waste Manag. and Res. 10: 485-503.

Tai, H.-S. a. W.-H. H. (2007). "A novel model of organic waste composting in Taiwan miliarty community." Waste Management 27: 10.

Tchobanoglous, G. and F. Kreith (2002). Handbook of Solid Waste Management. New York, McGraw Hill.

Tchobanoglous, G., H. Theisen, et al. (1993). Integrated Solid Waste Managment. Boston, MA, Irwin McGraw Hill.

Technologies, A. I. M. (2002). Integrated Solid Waste Management Plan Fort George G. Meade, Maryland. D. o. P. W. O. o. E. Management: 134.

UNEP/GRID-Arendal (2004). How long does it take for some commonly used products to biodegrade? [Internet]. [cited 2008 Jul 13]. UNEP/GRID-Arendal Maps and 
Graphics Library; http://maps.grida.no/go/graphic/how-long-does-it-take-forsome-commonly-used-products-to-biodegrade.

UNEP/GRID-Arendal (2006). Share of packaging waste in total household waste (OECD) [Internet]. [cited 2008 Jul 13]. . UNEP/GRID-Arendal Maps and Graphics Library; 2006. http://maps.grida.no/go/graphic/share_of_packaging_waste_in_total_household_ waste_oecd.

UNEP/GRID (2008). Share of packaging waste in total household waste (OECD) [Internet]. [cited 2008 Jul 13]. . UNEP/GRID-Arendal Maps and Graphics Library; 2006. http://maps.grida.no/go/graphic/share_of_packaging_waste_in_total_household_ waste_oecd.

USAirForce "Air Combat Command Solid Waste Program Management Guidance." 6. USArmy (1994). Office Waste Reduction Methods at Army Installations: 36.

USArmy (1994). Public Works Technical Bulletin 420-47-6, Waste Reduction Methods for Food Service Personnel at Army Installations C. f. P. Works.

USArmy (1994). "Source Reduction Planning, Public Works Technical Bulletin 420-4705."

USArmy (1999). Guide for Developing Integrated Solid Waste Management Plans at Army Installations. C. f. H. P. a. P. Medicine: 56.

USArmy (2007). Army Regulation 200-1, Environmental Quality Environmental Protection and Enhancement Headquarters. D. o. t. Army.

USCensusBureau (2000). Census of Population and Housing, http://factfinder.census.gov, accessed 6/1/2008.

USCoastGuard (1994). Beneficial Landscaping Guidance. U. D. o. H. S. U.S. Coast Guard Environmental Management Divison (G-SEC-3).

USDepartmentofState (2006). Greenhouse Gas Inventory, Fourth Climate Action Report to the UN Framework Convention on Climate Change.

Vaidyanathan, A., J. Mulholland, et al. (2007). "Characterization of fuel gas products from the treatment of solid waste streams with a plasma arc torch." Journal of Environmental Management 82(1): 77-82.

Weinick, H. (2008). Composting at Military Installations - - Impacts on Solid Waste Management. Sustainability of Solid Waste Managment. San Francisco, CA.

Young, R. (2007). "Composting Helps Fort Lewis Dump Garbage Burden " Northwest Guardian. 
Table 1. Demographics for military installations (US Census, 2000)

\begin{tabular}{|c|c|}
\hline Military population & US population \\
\hline The median age is 22 years & The median age is 35.3 years \\
\hline $23.2 \%$ from 18 to 24 & $25.6 \%$ under the age of 18 \\
\hline $36.8 \%$ under the age of 18 & $9.6 \%$ from 18 to 24 \\
\hline $38.1 \%$ from 25 to 44 & $30.2 \%$ from 25 to 44 \\
\hline $1.8 \%$ from 45 to 64 & $22.0 \%$ from 45 to 64 \\
\hline $0.2 \%$ who are 65 years of age or older & $12.4 \%$ who are 65 years of age or older \\
\hline $\begin{array}{l}\text { For every } 100 \text { females there are } 118.4 \\
\text { males. }\end{array}$ & For every 100 females there are 96.3 males. \\
\hline $\begin{array}{l}\text { For every } 100 \text { females age } 18 \text { and over, } \\
\text { there are } 125.3 \text { males. }\end{array}$ & $\begin{array}{l}\text { For every } 100 \text { females age } 18 \text { and over, } \\
\text { there are } 93.4 \text { males. }\end{array}$ \\
\hline
\end{tabular}


Table 2. Average Composition of MSW from Various Navy installation Sources (\% composition)

\begin{tabular}{|c|c|c|c|c|}
\hline $\begin{array}{l}\text { MSW } \\
\text { component }\end{array}$ & Commissary & Offices & Food service & Storehouses \\
\hline Paper & 84 & 72 & 67 & 64 \\
\hline Garbage & $<1$ & $<1$ & 5 & $<1$ \\
\hline Metal & 2 & 5 & 5 & 3 \\
\hline Textiles & $<1$ & $<1$ & $<1$ & $<1$ \\
\hline Plastic & 9 & 12 & 14 & 11 \\
\hline Leather & None & None & None & None \\
\hline Rubber & None & $<1$ & None & None \\
\hline Vegetation & $<1$ & 3 & $<1$ & $<1$ \\
\hline Inert & $<1$ & $<1$ & $<1$ & 1 \\
\hline Wood & 4 & 2 & 3 & 15 \\
\hline Glass & $<1$ & $<1$ & 4 & $<1$ \\
\hline Miscellaneous & $<1$ & 2 & $<1$ & 2 \\
\hline
\end{tabular}




\begin{tabular}{|c|c|c|c|}
\hline Type of Container & Cost & Advantages & Disadvantages \\
\hline Plastic Bags & \$0.12/bag & $\begin{array}{l}\text {-inexpensive } \\
\text {-light weight } \\
\text {-compact to store } \\
\text {-readily available } \\
\text {-single use }\end{array}$ & $\begin{array}{l}\text {-easily torn, scatters } \\
\text { materials } \\
\text {-plastic does not } \\
\text { decompose } \\
\text {-plastic may stay in } \\
\text { compost }\end{array}$ \\
\hline $\begin{array}{l}\text { Biodegradable } \\
\text { Plastic Bags }\end{array}$ & $\$ 0.20 / \mathrm{bag}$ & $\begin{array}{l}\text {-degrades in presence } \\
\text { of sunlight } \\
\text {-light weight } \\
\text {-compact to store } \\
\text {-readily available } \\
\text {-single use }\end{array}$ & $\begin{array}{l}\text {-rate of degradation is } \\
\text { uncertain } \\
\text {-more expensive than } \\
\text { plastic }\end{array}$ \\
\hline Paper Bags & $\$ 0.25-0.45 /$ bag & $\begin{array}{l}\text {-more durable than } \\
\text { plastic } \\
\text {-degradable in } \\
\text { composting process }\end{array}$ & $\begin{array}{l}\text {-more expensive than } \\
\text { plastic } \\
\text {-not structurally stable } \\
\text { when wet unless } \\
\text { coated with plastic } \\
\text { which will limit } \\
\text { compost potential }\end{array}$ \\
\hline Rigid Plastic Bins & $\$ 50-60 /$ ton & $\begin{array}{l}\text {-practical size (30- 90- } \\
\text { gallons) } \\
\text {-easy for mechanical } \\
\text { pick-up } \\
\text {-wheels, large size, } \\
\text { increase ease of use }\end{array}$ & $\begin{array}{l}\text {-initial cost are high } \\
\text {-Extra collection time } \\
\text {-infrequent collection } \\
\text { could cause odor } \\
\text { problems }\end{array}$ \\
\hline
\end{tabular}




\begin{tabular}{|c|c|c|}
\hline Item & Locations/Sources & Preparation Required \\
\hline Batteries & Offices, stores, motor pools, & Posting, containers \\
\hline $\begin{array}{l}\text { Corrugated Cardboard } \\
\text { (OCC) }\end{array}$ & $\begin{array}{c}\text { Offices, commissary, stores, } \\
\text { supply issue points, motor } \\
\text { pools }\end{array}$ & Flatten, provide bin \\
\hline $\begin{array}{l}\text { Glass, Plastic, Al, steel, tin } \\
\text { containers }\end{array}$ & $\begin{array}{l}\text { Offices, clubs, lounges, } \\
\text { MFH, mess halls }\end{array}$ & $\begin{array}{l}\text { Rinsing, Posting, } \\
\text { Receptacle }\end{array}$ \\
\hline $\begin{array}{l}\text { Laser Printer/Copier } \\
\text { Cartridges }\end{array}$ & Offices, supply issue points & $\begin{array}{l}\text { Place in box of newly } \\
\text { installed cartridges, ship } \\
\text { back to manufacturer }\end{array}$ \\
\hline Leaves and Yard waste & Landscaping, MFH & $\begin{array}{l}\text { Place in paper bags or } \\
\text { designated receptacles }\end{array}$ \\
\hline $\begin{array}{l}\text { Paper(office, newspaper, } \\
\text { colored, magazines, glossy) }\end{array}$ & $\begin{array}{l}\text { Offices, schools, clubs, } \\
\text { lounges, MFH, mess halls }\end{array}$ & Bins, posting \\
\hline Scrap Metal & $\begin{array}{l}\text { Renovation, demolition, } \\
\text { O\&M shops }\end{array}$ & $\begin{array}{l}\text { Separation from non-metal } \\
\text { components }\end{array}$ \\
\hline Waste Oil & Motor pools, shops, MFH & $\begin{array}{l}\text { Collection container, } \\
\text { collection service }\end{array}$ \\
\hline
\end{tabular}


Table 5. Suggested items for recycling (US EPA)

\begin{tabular}{lll}
\hline Animal Manure & Fireplace ashes & Nut shells \\
Cardboard rolls & Fruits and vegetables & Sawdust \\
Clean paper & Grass Clippings & Shredded newspaper \\
Coffee grounds \& filter & Hair and fur & Tea bags \\
Cotton rags & Hay and Straw & Wood chips \\
Dryer lint & Houseplants & Wool rags \\
Eggshells & Leaves & Yard trimming \\
& & \\
\hline
\end{tabular}




\begin{tabular}{|c|c|c|c|c|c|}
\hline & \multicolumn{3}{|c|}{ Small Waste Incinerators } & \multicolumn{2}{|c|}{ Large Incinerators } \\
\hline $\mathrm{PPM}, \mathrm{mg} / \mathrm{m}^{3}$ & $\begin{array}{c}\text { Class A } \\
27\end{array}$ & $\begin{array}{c}\text { Class B } \\
34\end{array}$ & $\begin{array}{r}\text { Class C } \\
70\end{array}$ & $\begin{array}{l}\text { New } \\
24\end{array}$ & $\begin{array}{r}\text { Existing } \\
27\end{array}$ \\
\hline $\begin{array}{l}\text { Dioxins and } \\
\text { Furans, ng/ }{ }^{3}\end{array}$ & 30 & 123 & 125 & 13 & 30 \\
\hline $\mathrm{Pb}, \mathrm{mg} / \mathrm{m}^{3}$ & 0.49 & 1.6 & 1.6 & 0.2 & 0.44 \\
\hline $\mathrm{Cd}, \mathrm{mg} / \mathrm{m}^{3}$ & 0.04 & 0.1 & 0.1 & 0.02 & 0.04 \\
\hline $\mathrm{Hg}, \mathrm{mg} / \mathrm{m}^{3}$ & & & $\begin{array}{r}0.080 \\
\text { (or 85\% reduc }\end{array}$ & & \\
\hline $\mathrm{HCl}, \mathrm{ppmv}$ & & $\begin{array}{c}200 \\
\text { (or } 50 \% \text { red) }\end{array}$ & $\begin{array}{c}250 \\
\text { (or 50\% red) }\end{array}$ & $\begin{array}{c}25 \\
\text { (or } 95 \% \text { red) }\end{array}$ & 31 \\
\hline $\mathrm{SO}_{2}, \mathrm{ppmv}$ & & $\begin{array}{c}55 \\
\text { (or } 50 \% \text { red) }\end{array}$ & $\begin{array}{c}80 \\
\text { (or 50\% red) }\end{array}$ & $\begin{array}{c}30 \\
\text { (or } 80 \% \text { red) }\end{array}$ & 31 \\
\hline
\end{tabular}




\begin{tabular}{|c|c|c|c|c|c|c|c|c|}
\hline Metric & $\begin{array}{c}\text { Source } \\
\text { Reduction }\end{array}$ & Landfilling & Recycling & Incineration & Composting & $\begin{array}{c}\text { Bio- } \\
\text { reactors }\end{array}$ & Pyrolysis & Plasma Arc \\
\hline Ready to Use & 5 & 5 & 5 & 3 & 2 & 1 & 3 & 1 \\
\hline $\begin{array}{l}\text { Ease of Use (waste } \\
\text { producer) }\end{array}$ & 4 & 5 & 4 & 5 & 3 & 5 & 5 & 5 \\
\hline Ease of Use (operator) & 4 & 3 & 4 & 3 & 2 & 1 & 3 & 2 \\
\hline $\begin{array}{l}\text { Technical skills } \\
\text { required for long term } \\
\text { management }\end{array}$ & 3 & 2 & 3 & 2 & 2 & 2 & 3 & 1 \\
\hline Infrastructure needs & 5 & 1 & 4 & 1 & 3 & 1 & 1 & 1 \\
\hline Land use needs & 5 & 1 & 4 & 2 & 3 & 3 & 3 & 3 \\
\hline $\begin{array}{l}\text { Carbon/greenhouse gas } \\
\text { emissions }\end{array}$ & 5 & 1 & 4 & 1 & 4 & 3 & 2 & 3 \\
\hline $\begin{array}{l}\text { Potential for long term } \\
\text { environmental damage } \\
\text { to soil, air water }\end{array}$ & 5 & 2 & 4 & 2 & 5 & 3 & 3 & 4 \\
\hline $\begin{array}{l}\text { Social and or/ market } \\
\text { acceptance }\end{array}$ & 4 & 5 & 4 & 3 & 4 & 1 & 3 & 3 \\
\hline $\begin{array}{l}\text { Waste reduction (to } \\
\text { landfills) }\end{array}$ & 5 & 1 & 5 & 4 & 5 & 4 & 4 & 5 \\
\hline $\begin{array}{l}\text { Energy } \\
\text { savings/production }\end{array}$ & 5 & 2 & 5 & 3 & 5 & 3 & 3 & 3 \\
\hline Cost & 5 & 2 & 5 & 3 & 4 & 3 & 3 & 2 \\
\hline Totals & 50 & 30 & 51 & 32 & 42 & 30 & 36 & 33 \\
\hline
\end{tabular}

Page | 37 
Figure 1. Share of packaging waste in total household waste. (UNEP/GRID-Arendal 2006)

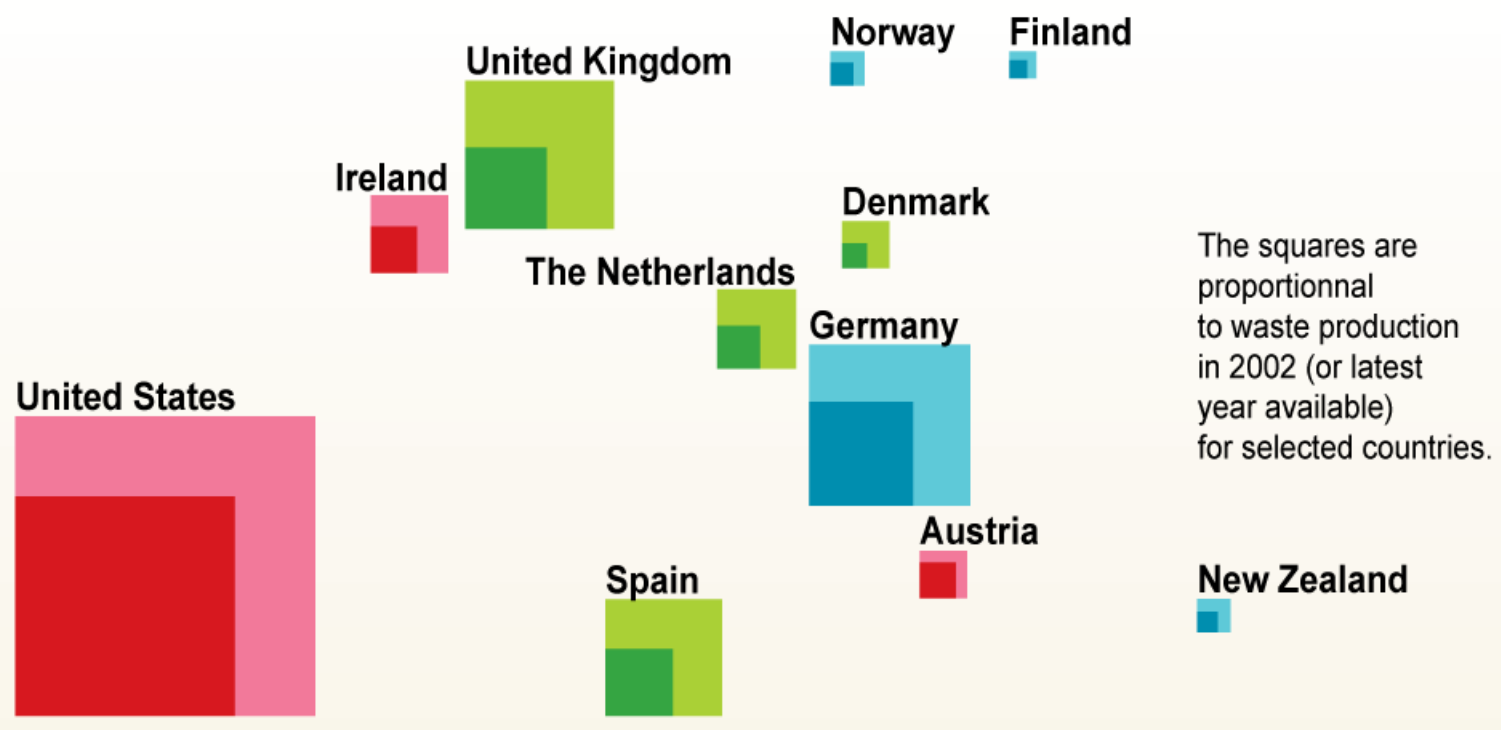

Waste production in thousand tonnes

Sources: OECD Environmental Data 2004.
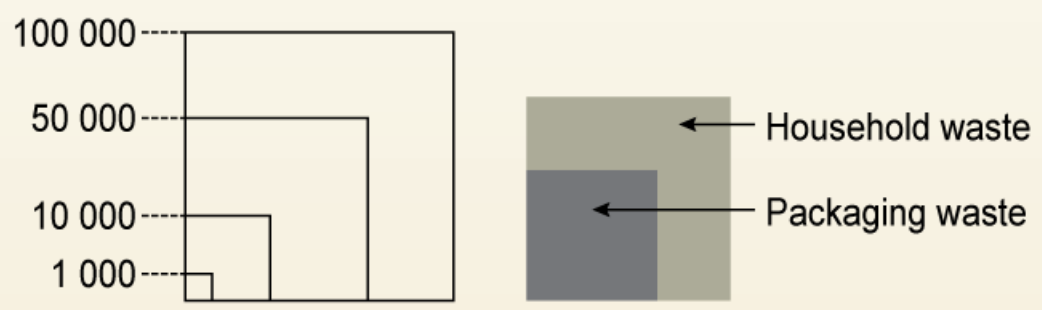

Share of packaging waste in total household waste:

Higher than $50 \%$ Between 33 and $50 \% \quad$ Lower than $33 \%$ 
Figure 2. Biodegradation rates of MSW components (UNEP/GRID-Arendal 2004)

How long does it take for some commonly used products to biodegrade?

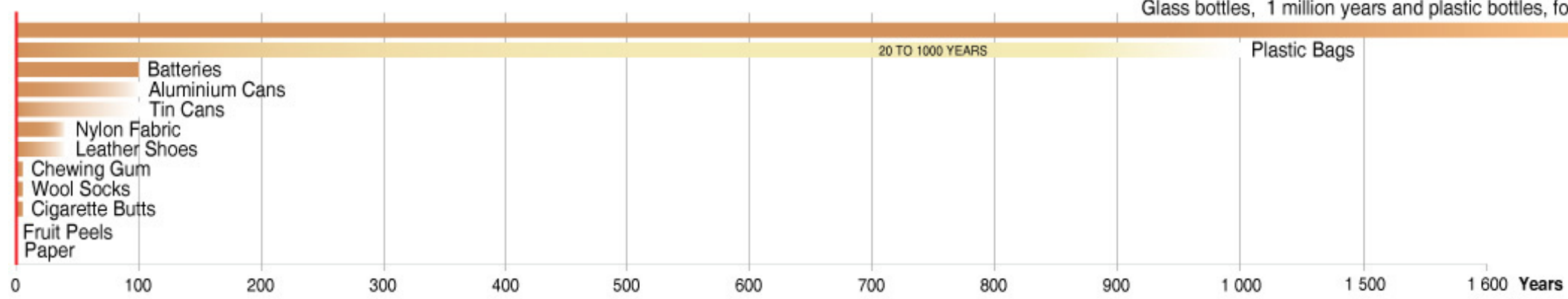

Source: The Coral Reef Alliance \& Worldwise 
Figure 3. 2004 Methane sources (USDepartmentofState 2006)

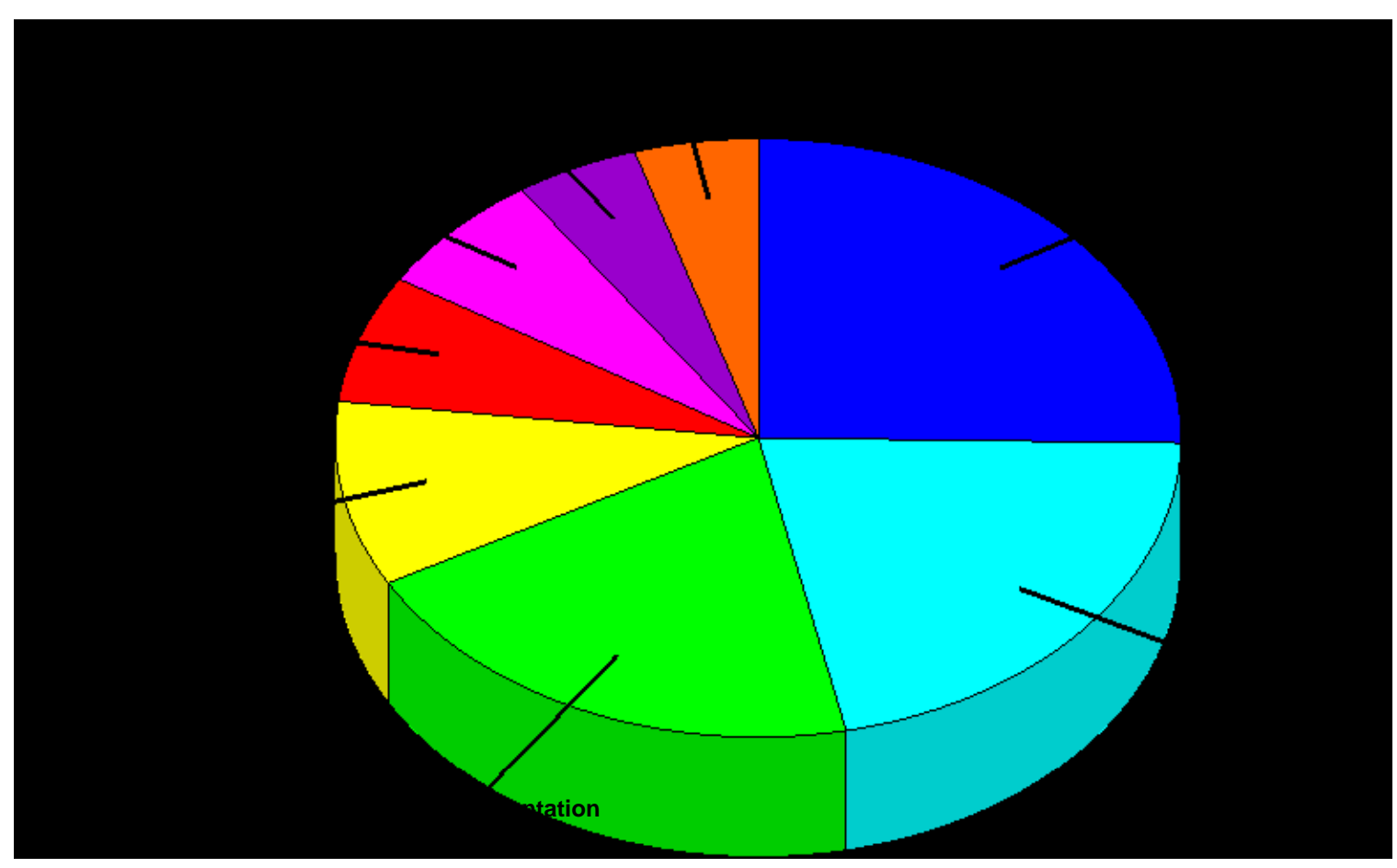

Page | 40 
Figure 4: Settling Rates of Bioreactor Landfills showing increased settling from the aerobic treatment.

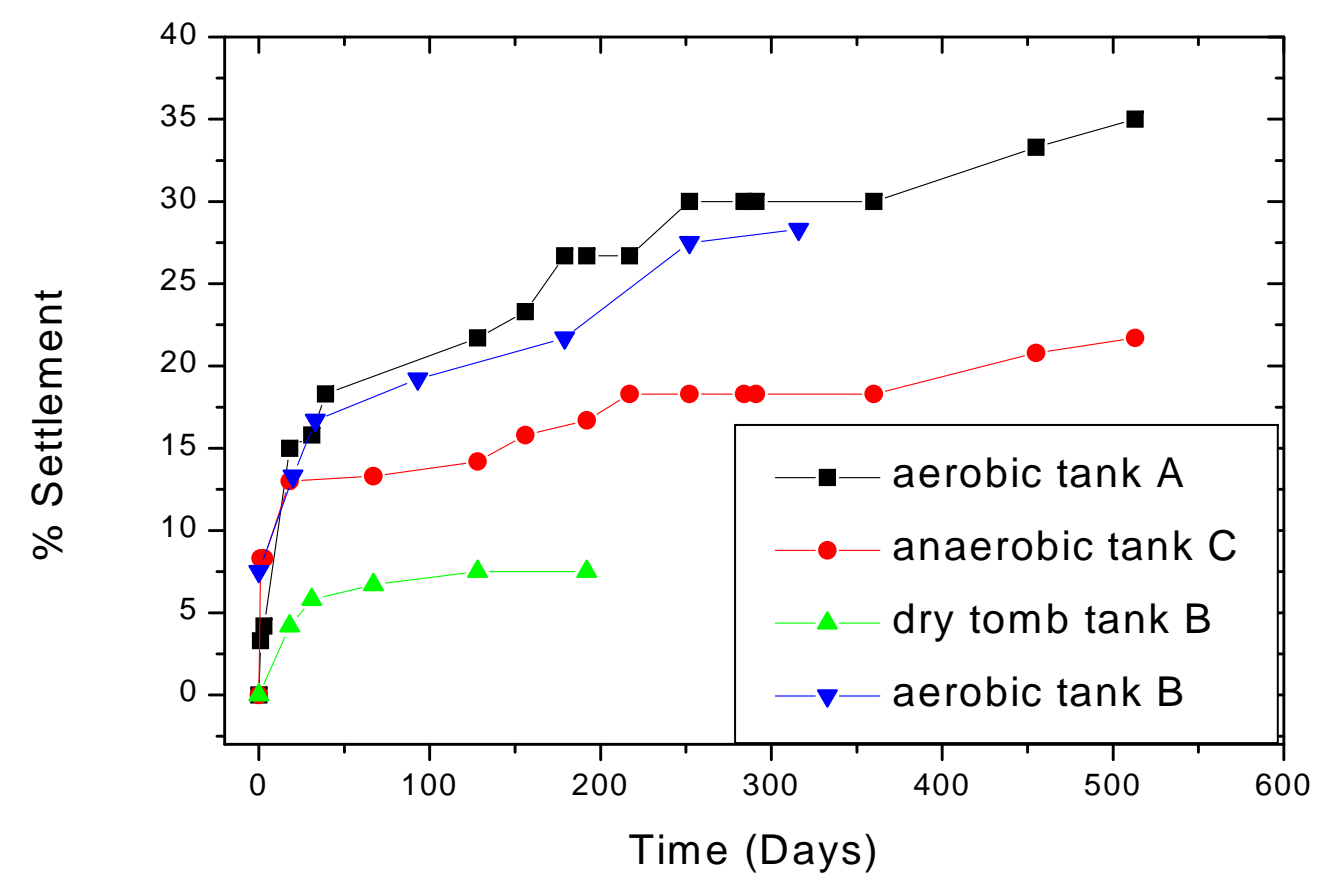

Page | 41 